\title{
The Use of Deixis in Students' Speech Text at Ma'had Sunan Ampel Al-Aly Dormitory Universitas Islam Negeri Malang
}

\author{
Nadiyatul Uswatul Hasanah, Januariyus Mujianto, Dwi Rukmini \\ Universitas Negeri Semarang \\ nahdinnadiya@gmail.com
}

Article History $\quad$ Received : January $13^{\text {th }} 2021$

Revision : February 27th 2021

Publication : March 30th 2021

\begin{abstract}
Through in the finding product of speech text, students' can speech their knowledge, thoughts, and feeling to the listener. Deixis is one of parts in pragmatics. Deixis is parts hold intimate relation between textual meaning and context. And one of the speech text components that have to be show by the students' to communicate the meaning in speech text. This study aimed at identifying the use of deixis in the students' speech text at Ma'had Sunan Ampel Al-Aly Dormitory Universities Islam Negeri Malang and focus on how they realized in different texts. Descriptive qualitative method is used in this research. Eight research texts were chosen as the sample for analysis. The result shows that the speech text use all kinds of deixis, the use of person deixis is more dominant. Because the position of the speaker as the main characters is themselves of their own knowledge. The proximal form is more dominant rather than the distal form in the place deixis. In the time deixis was used by present time, past time, and future time. In the social deixis was used in two parts. Therefore, absolute social deixis and relational social deixis. After that in the discourse deixis used through discourse marker and form of demonstrative this/that. Also, deixis is highly context-dependent that is cannot be understood without considering the context. Therefore, in realizing students' speech texts, English learners cannot only understand in the whole context of the students' speech text also trust on their vocabularies need. Because of this research for the future can improve knowledge of pragmatics especially in the speech text of deixis.
\end{abstract}

Keywords: Deixis, type of deixis, speaking.

\section{INTRODUCTION}

Speaking is one of master skill in English. English one of main concern to foreign language or second-language learners. According to Kayi (2006, p.1) definition of speaking is the way of share and build purpose during in the way of non-verbal and verbal in kinds of context. So, one way to implication of 
speaking except communication is speech.

Speech is a communication related by a speaker to the audience or listener in an event. The sample of speaking in communication directly of one person to the listener is speech. In communication has one function of language is referential meaning which means the expression to talk about objects or events that take in the environment. In relation of English education students, language has been familiar with five major fields of studies of the English language. They are phonology, morphology, syntax, semantics, and pragmatics. One of the topics in English language study in which the researcher is interested is pragmatics.

Levinson (2008) that the study of connection both of the context and the language in grammatical is definition of pragmatic. So, the relation both of the contect and the language is defined of pragmatic.

Deixis is form of linguistic used for represent of point. Other name of deixis is deictic. To understand of purpose or meaning of phenomenon in the word and phrases in the context of utterance information is the function deixis in the lingusitic.

Levinson (2004) defines is categories of five deixis there are; time, person, discourse, social, and place deixis.

Speech makes the explanation effective to be understood by the audience and make the various utterances of the teacher. Besides, using deixis in speaker utterance, speaker taught the audience about the pronoun and the references in communication. Students' ability to comunication effective and easy is goal of learning speaking.

Speech is one of the annual programs in this Islamic Boarding School of University. One of way how is improve skill of students in the speaking. From my experience of study in Ma'had Sunan Ampel Al-Aly and This study was worth to investigated since preliminary research, there are some problem in that found faced by the students speech at Ma'had Sunan Ampel Al-Aly dormitory. The researcher gets more of student difficult to identifying terms of deictic to understand of a sentence in the word. Because difficult to get the meaning of the word. Focus learning english skill in asian such as indonesian, china, and japan. The learning skill focus on reading and grammar in the proces learning classroom. (Schmidt (2019); Uleanya, Uleanya, \& Olayemi (2019); Yang \& Quadir (2018); Musthafa \& Tresnawati (2016).

Furthermore, the use of deixis on students' speech text contributed to the students' clear when performance in front of listener. Since deixis has an important role to describe what was being talked about, it was meaningful. This study mainly focused on the use of pragmatic deixis in students' speech text. Based on the researcher's preliminary research, the students of University still have difficulties 
in write speech text. Then, the researcher would find out the main problem of their difficulties especially in the use of deixis and present how is the relation of type deixis used by students' speech text.

According to Levinson (2008) stated deixis is classified into: place deixis, person deixis, time deixis, discourse deixis and social deixis. Identification of the grammatical person used to refer to speaker and addressee and concerns the encoding of the role participan in the speech even is person deixis. Inform the location is Place deixis. The words indicating place deixis in two parts forms. They are proximal form and distal form. Example“There, Here, This, That". Identification of period the speaker produced by utterance is time deixis. that time deixis are present time, past time, future time. For example "today", "tomorrow", and "yesterday". Identification of relationship between information to people in society by language is social deixis. identification of speaker's present location near or far. Such as that, this, similliraty, therefore.

Moreover, Hutauruk (2018) studied deixis in writing texts. In her study showed that the result is deixis can be found in daily life communication in written style, without realizing we use it for example when the readers get a new text, they need to get information about who are the speaker and the hearer, where, and when the events take place. The information can be accessed through the understanding of the written text.

Furthermore, Khalilli (2017) investigated deixis in the novel. In his research showed that the result is the most dominant personal deixis found in that novel. It was related to the existence of characters as the taking narrative and making a storyline. They also found time deixis, place deixis, social deixis, and discourse deixis in the novel.

Moreover, Miftah (2016) investigated deixis in the newspaper. The result of their research showed that pragmatics is something to do with context. The use of deixis can carry implicit meaning to reader. We need to seek the actual meaning of the text. Different circle instances lead people to have a different thought in their mind.

However, the previous study only observed the use of deixis in the form of writing text, novels, newspaper, and etc. They were also observing students competence in interpreting deixis. This current study attempts to examine the realization of deixis in students writing texts using Levinson (2004) theory, find out the students difficulties in using deixis, and explain the teacher's roles to overcome the students' difficulties. Thus, none of the previous studies analyzed the students' speech texts, the relation of type deixis different in students' speech text. 
Volume 4 Number 3 March 2021

\section{METHOD}

This research uses descriptive qualitative method was applied. This study is to explore the deixis used by Students 'of University in speech text.The researcher chooses 8 students speech text of the one month in December 2019.The instrument of this study. The researcher uses table for presenting the objectives, which become the focus of the study.

In collecting data, the researcher collects data from teacher of students' of University speech. Then, the researcher does to comprehend the information of the text speech by read all the speech texts. After that, the researcher chose eight text of speech performance in one month. The last steps of analyzing the data were as follow: (1) Identifying, (2) Classifying, (3) Analyzing, and (4) Interpreting.

\section{RESULTS AND DISCUSSION}

The use of deixis in student's of university speech text. The researcher found on data analysis, there are six point, (1) person deixis in student's of university speech text, (2) place deixis in student's of university speech text, (3) time deixis in student's of university speech text, (4) social deixis in student's of university speech text, (5) discourse deixis in student's of university speech text, (6) the relation of deixis in student's of university speech text.

Firts, the use of person deixis in students' speech texts at Ma'had Sunan Ampel Al-Aly Dormitory Universitas Islam Negeri Malang. Person deixis analysis in students' speech texts divided into three parts. First, the first- person deixis, it was divided into two parts; first-person singular and first person plural. The analysis of "I "person showed that the students put themselves as the main subject in their speech texts since I"' person is the person who speaks the utterance. Here the examples from the students' speech texts show in datum (1). In datum (1), Finally I say Wassalamu'alaikum. Then, show in datum (2). In datum (2), We must tell ourselves that honest y is better than everything.

The students' used 1"peson of plural " 1 " and "We" as subject pronoun. The deictic word " 1 " can be categorized in the first of singular person that 1stsingular person that referee in students as the speakers while "We" categorized as first person plural. Therefore, the deictic words " 1 " and "We" used to show their own experience in their speech text. As stated by Hutauruk (2018), she argued that the writer used the first of person deixis. "I" to refree herself who expressed her/his understanding, her/his feeling, her/his thinking. The deictic of the word "We" defined a deictic express that the speaker used deictic word "We" in the text.

After that, the second of person deixis, the 2nd person singular in their 
speech text encoded by the use of the deictic words "You" and "Your" The deictic word 'Jon" can be interpreted as the addressed or who someone has contact direction with 1 st of person deixis. Someone who has direct contact with the 1st person. The researcher in the data not get 2 nd plural of person deixis. Deictic reference of second in the person deixis. Example of second in person deixis are 'Jon, yourself, yourselves, your, yours". Here an example from the students' speech texts in datum 3. In datum 3, Thank you dear MC for your kindness to let me come forward and deliver my speech before the audience.

In the example above showed that the 2 nd person singular showed the dialogue occurred between speakers to the listener especially MC in the performance. The speaker that was the student used the 2nd pronoun of "You" refers to the listener to say Thanks.

In addition, the third of person deixis, the speaker use 3rd person person deixis, that to showed in the spech text is neither or speaker. That's all that found in the students' speech text were he, him, his she, her, it. The third plural person were they, them, their. The third person deictic were the determinatives personal pronouns "he" "she", "it", "they revel gender and the number of the pronoun. Here the examples in the students' speech texts in the dantum (4). In datum (4), So, let's praise Him. And in datum (5). In datum (5), She always happiness when see happy of us.

In the example the students as a speaker showed that the 3rd person singular. The deictic word "him" referred to God Alloh. Speakers' is let's to audience for pray to God Alloh. Further, the deictic "she" in the example above referred to remerging to audience. Mother can feel happiness when see a son happy.

Second, the use of place deixis in students' speech texts at Ma'had Sunan Ampel Al-Aly Dormitory Universitas Islam Negeri Malang. In the place deixis the researcher focused on two part. There are proximal form (close the speaker) and distal form (close of addressee is not proximal). As stated by Gjergji (2015), there is the proximal place deixis (close the speaker) for example these and this. Example of distal place deixis (close of adresee) is that and those. Both of them use other noun combination and pronoun. The example from the speakers in dantum (6). In dantum (6), We are very glad because tonight we can meet in this place safe and sound. Then, in dantum (7). Dantum 7, Prophet Muhammad himself did not hesitate to deal in a friendly way with unbelief are who opposed him in Makkah.

The speaker use "in this place" in this example divided a proxymal form. Because location is near from the speakers. Further, the speaker use word "in Makkah" referred the location is far from the speaker. So, the word "in Makkah" divided to distal form.

It word of "This" is means close of the speakers of location at the code of 
time rather than the pragmatically give an area. Further, the student also used place deixis "there" in the example above. Could be distal form it means the speaker is so far from the location of student's speech. The other utterance "There" meant is the chair that far away from the student at that time.

It word of "there" is means of receive time of addressees could be proximal or code time of location could be distant. Time Deixis in Students' Writing relative is spans of time in the word of utterance and include in temporal point.

Third, the use of time deixis in students' speech texts at Ma'had Sunan Ampel Al-Aly Dormitory Universitas Islam Negeri Malang. Time deixis give a specific point of time of the utterance. English needs tenses system which indicates when an action happens to give a specific time of the action. Further, the researcher focused on the use of time deixis in the form of past time, present time, and future time in the students' speech texts. This example is the students' speech texts in datum (8). In datum 8, today, we can see Muslimah wearing jilbab not only in religious meetings or in Islamic schools but we can also see them almost anywhere. And show in datum (9). In datum (9), if people were of the same profusion and expertise. Then, in datum (10). In datum (10), he will also guide them to the straight path.

In the example above, the word "today" identified as the time. The words "here" referred to time deixis that identified as a proximal term. It showed the past condition. Although, the word "were" did not show additional particle or adverbial of time to indicate time reference. The clause used simple past tense that refers to the past time. It referred to the day after the time speaking. That's all about past and present tense. Because in the future use modal verb like shall and can or phrasal modal like going to. Divide of the example is future tense.

Fourth, the use of social deixis in students' speech texts at Ma'had Sunan Ampel Al-Aly Dormitory Universitas Islam Negeri Malang. In this social deixis the researcher showed the difference of social status and participants of communication express the relationships in society through language.

Khalili (2017), he stated that social deixis refers to the social ranking and positions between the speaker and the addressee in the society using language. The researcher focused on the analysis of social deixis in the form of relational social deixis and absolute social deixis. Here show the examples from the students" speech texts in datum (11). In datum (11), Mother is person behind's someone's success. Then, show the example in datum (12). In datum (12), "Sorry, Mr, or Mrs..."

There was social deixis "Mother" showed the social relationship between the son and parents. Further, in the example "M r" and "Mrs" the student used relational social deixis since they had a kind ship relationship as a daughter, older person.

It was proven by Khalili (2017) who argued that relation in social deixis 
divided in the social of characters and social of relationship both of speaker and addresses in the part of deictic. Example of lexical in the object is my husband, teacher, son, etc. Moreover, from data in the findings, the student put a little conversation between the student and his lecturer. It used make to the reader get the context with easy point in the story. In the example above, the student used "Sir" to mention his lecturer when he asked about his fault that caused him to be expelled from the class. The deictic word "Sir" was absolute social deixis since the writer showed his formal respect at the class to his colleagues

It was in line with Khalili (2017) who argue that social deixis referee of deictic include in the not relation with the ranking or in the place of addressee and speaker. Such as Mr. President, Your highness, you're Majesty. etc.

Fifth, the use of discourse deixis in students' speech texts at Ma'had Sunan Ampel Al-Aly Dormitory Universitas Islam Negeri Malang. Discourse Deixis in Students' speaking Discourse deixis was a deictic reference to the portion of discourse relative to the speaker's stream "location" in the discourse.

As stated by Pangaribuan et.all (2015), that means is refers to the text deixis is discourse deixis. Sometimes, discourse deixis is referred in the use of expression in the word. In other hand discourse deixis is relative in the speaker's stream of discourse. The researcher divided discourse deixis into two parts; they were the demonstrative that/this and the discourse marker. Here the examples from the students" speech texts show in datum (13). In datum (13), we are sure that Muslimah will look more beautiful when they put their jilbab on. And show in datum (14). In datum (14), this is the end of my speech. Then show in datum (15). In datum (15), well, let me try tonight to talk about: Life under the Guidance.

For the example the word "that" referred as discourse deictic expression. Because of the referred is prior of the patron in the discourse deixis.

After analyzing all the data, discourse of deixis "that" referred to a bad situation that the student had in the past. It meant that the student as the writer delivered to the reader about her situation when she bullied in the past. Then, her best friend supported her in that situation. Further, there was also discourse deixis "this" in the example above. The word "this" could be categorized of discourse deixis was used in the point out of student unforgettable day. It referred to an upcoming portion of the discourse, while the student explained her unforgettable day in the next. It was in line with Pangaribuan et.all (2015) who argued that demonstrative "this" refer to a forthcoming in the discourse. "That" is mean preciseness in the portion. Moreover, discourse deixis "but" also found in the example above. The deictic word "well" was a discourse marker since it refers to a referent previously mentioned. In the example above, the student wanted to show to the reader about her 
experience when the earthquake disaster happened in her town. She thought it was a nightmare, and then she used the word "well" to contrast with her thought. It was a real disaster.

In this study she argued that deictic reference of portion or relative in the speakers is discourse deixis. For example; so, but, similarity, further, moreover.

Sixth, the realized in different texts of type deixis in students' speech texts at Ma'had Sunan Ampel Al-Aly Dormitory Universitas Islam Negeri Malang. The researcher showed the realized in structure of language and in the language used. Because contexts haven't meaning Thus, deixis types are a clearly to describe the structure of language in the relation both of the use of context and language. In a speech text there must use deixis. Because deixis is very important for the listener to understanding of the word that the speaker speech. It will easy to understand and word suitable to get the point. So, it make easy apply deixis to process teaching learning at Ma'had Sunan Ampel Al-aly dormitory Universitas Islam Negeri Malang.

Overall the calculation of deixis frequency shows that person deixis is the most used deixis in the eight speech texts by 231, this is because speech texts focus on speaker and listener. It is followed by time deixis 157, social deixis 107, discourse deixis by 96 , and the last is place deixis 26 . The results have been summarized in the following table.1.

Tabel. 1

\begin{tabular}{|c|c|c|c|c|c|c|c|}
\hline \multirow{2}{*}{ No } & \multirow{2}{*}{ Text } & \multicolumn{5}{|c|}{ Deixis } & \multirow{2}{*}{ Total } \\
\hline & & Person & Time & Place & Discourse & Social & \\
\hline 1 & Text 1 & 15 & 15 & 10 & 14 & 17 & 71 \\
\hline 2 & Text 2 & 38 & 32 & 1 & 17 & 15 & 103 \\
\hline 3 & Text 3 & 32 & 18 & 1 & 10 & 13 & 74 \\
\hline 4 & Text 4 & 16 & 16 & 1 & 13 & 14 & 60 \\
\hline 5 & Text 5 & 27 & 10 & 1 & 10 & 8 & 56 \\
\hline 6 & Text 6 & 39 & 17 & 8 & 12 & 13 & 89 \\
\hline 7 & Text 7 & 38 & 24 & 1 & 10 & 24 & 97 \\
\hline 8 & Text 8 & 26 & 25 & 3 & 10 & 3 & 67 \\
\hline \multicolumn{2}{|c|}{ Total } & 231 & 157 & 26 & 96 & 107 & 617 \\
\hline
\end{tabular}

\section{CONCLUSION}

Based on the finding, some conclusions of this thesis can be drawn. The main characters of their speech text in students' speech text at Ma'had Sunan Ampel AlAly Dormitory Universitas Islam Negeri Malang all types of deixis including person deixis, place deixis, time deixis, social deixis and discourse deixis. Furthermore, the most dominant in speech texts is person deixis. Because in the speech texts the 
speakers give more knowledge, idea, to audience.

Furthermore, deixis is highly context-dependent that is cannot be understood without considering the context. Therefore, in realizing students' speech texts, English learners cannot only understand in the whole context of the students' speech text also trust on their vocabularies need. Besides, deixis is not only used to refer to specific point ut also to give a particular sense to the text. For example the use of in Madinah, in Makkah, and there. All of sentence of the text is very far location from the speakers.

In speech text. The 2nd person of deixis used to refer to one person or addressee. Then, the 3rd person deixis used to refers to the utterance use implies the gender or speaker that no identification. Students used place deixis to refer to the place where the context of the speech. The speaker used the proximal form to show to the listeners the location that was close to them as the speaker of the speech to indicate the location happened in their speech. In contrast with proximal form of place deixis, the speaker also used the distal form to show to the listener the location that was far from them as the speaker of the speech to indicate the location happened in their speech. Time deixis was realized in the present time, past time, future time and adverbial time. In the students' speech texts. The students also often to use the past time indicated of time deixis since they asked to explain about knowledge in the past. The students used the present time to show to the audience the activity that occurs regularly. Then, the students also used adverbial of time to express future time. Social deixis was realized through relational social deixis and absolute social deixis in the students' speech texts. The students were used to relational social deixis in informal situations. In contrast with relational social deixis, the students used absolute relational social of deixis. In the formal of situations. Speakers uses discourse deixis in the text of demonstrative is this/that to encode reference to the prior of discourse depends on the location of demonstrative this/that. Meanwhile, the students also used discourse marker that identified of discourse deixis. Discourse marker so, but, and furthermore referred to a referent previously mentioned.

\section{REFERENCES}

Gjergji, S. (2015). A Pragmatic analyses of the use of types of deixis in poetry and novels of the author Ismail Kadare. Academicus International Scientific Journal. https://www.ceeol.com/search/article-detail?id=289510

Hutauruk, B.S. (2018). Stylistic analysis of deictic expressions used on EFL written essay grade Ill at English Department at FKIP UHN Pematangsiantar. Journal of English Language and Culture, https://journal.ubm.ac.id/index.php/english-laneuaee-culture/a rticle/view/1094

Kayi, H. (2006). Teaching Speaking: Activities to Promote in Second Language. TSL Journal: http://itslj.org.article/kayiteaching.htm 
Khalili, E. (2017). Deixis analysis in a tale of two cities written by Charles Dickens. Interimtional Academic Jurnal of Social Sciences, http://iaiest.com/dl/journals/3Clio20of\&o20Sciences/v4-i3-ful-sep2017/paper0.pdf

Levinson, S.C. (2004) the Handbook of Pragmatics. Ed. Horn, L.R and Ward, G. Cornwall: Blackwell Publishing.

Levinson, Stephen C. (2008). Pragmatics. 19thn edition. Cambridge: Cambridge University.

Miftah, M.Z. (2016). Analysis of deixis in the article selected from the Jakarta Post. The Proceedings of International Conference. https://www.researchgate.net/profile/Karva_Ilmiah_Tadris_Bahasa_Inggris/publicatio $\mathrm{n} /$

Pangaribuan, R. E., Manik, S., \&Pasaribu, T. (2015). Deixis used on business brochures text: A pragmatics study. International Journal of English $\begin{array}{lll}\text { Linguistics, } & 5(5), & 171 .\end{array}$ http://www.ccsenet.org/journal/index.php/ijel/article/donwload/53694/28749

Schmidt, L. M. (2019). Trauma in English learners: Examining the influence of previous trauma and PTSD on English learners and within the classroom. TESOL Journal, 10 (1), 1-10. https://doi.org/10.1002/tesj.412.

Musthafa, B., \&Tresnawati, F., (2016). Expressive writing in minimizing students' public speaking anxiety. 1 st UPI International Conference on Sociology Education (UPI ICSE 2015)393-399. https://doi.org/10.2991/icse15.2016.85.

Uleanya, C., Uleanya, M. O., \& Olayemi, S. (2019). Revisiting high school teachers education: Solution to sustainable development in rural Africa. Cogent Social Sciences, 5 (1),1-15 https://doi.org/10.1080/23311886.2019.1653545

Yang, J.C., \& Quardir, B. (2018). Effects of prior knowledge on learning performance and anxiety in an English learning online role-playing game. Educational Technology and Society, 21(3), 174-185. 